\title{
A Comparison of Respiratory Processes in Spirillum volutans, Spirillum itersonii and Spirillum serpens
}

\author{
By J. A. COLE* AND S. C. RITTENBERG \\ Department of Bacteriology, University of California, \\ Los Angeles, California 90024, U.S.A.
}

(Accepted for publication I5 September I97I)

\begin{abstract}
SUMMARY
Respiratory processes in Spirillum serpens and $S$. itersonii were compared with those in the microaerophile $S$. volutans. Rates of oxygen consumption with various substrates and the catalase activity were lower in $S$. volutans. The activities of five citric acid cycle enzymes and reduced nicotinamide adenine dinucleotide oxidase in cell-free extracts were also I0- to 200-fold lower. The concentration of cytochrome $c$ was greater in the oxygen-insensitive spirilla. This may explain the poor growth of $S$. volutans: it is unlikely that the complete inhibition of growth in aerated cultures is due to a haemoprotein deficiency.
\end{abstract}

\section{INTRODUCTION}

Spirillum volutans, first mentioned in $\mathrm{I} 830$, was described by Ehrenberg ( 1838 ). It is a large, polarly flagellated spirillum containing characteristic storage granules. The width of the organism, about $2 \mu \mathrm{m}$., is constant, but its length varies from ro $\mu \mathrm{m}$. in young, rapidly dividing cultures to more than $100 \mu \mathrm{m}$. during the late stationary phase (Williams \& Rittenberg, I957).

Wells \& Krieg (1965) cultured Spirillum volutans in nutrient broth without supplementation by equilibrating the medium with environments of reduced oxygen concentration. Growth occurred in a $9 \%$ but not in a $12 \%$ oxygen atmosphere with an inoculum of about $\mathrm{I} \cdot 4 \times \mathrm{IO}^{3}$ spirilla $/ \mathrm{ml}$. In its sensitivity to oxygen, $S$. volutans differed from the smaller spirilla which grew readily from small inocula in media equilibrated with air. In this work the respiratory processes in $S$. volutans were compared to $S$. itersonii and $S$. serpens, to determine whether significant differences exist which might explain its oxygen sensitivity.

\section{METHODS}

Organisms and media. The Pringsheim strain of Spirillum volutans studied by Rittenberg \& Rittenberg (1962) was used. Spirillum itersonii and S. serpens, from the departmental culture collection, were maintained on Krieg's (McElroy, Wells \& Krieg, I967) medium (I g. sodium succinate, Io g. Bactopeptone (Difco), I g. $\left(\mathrm{NH}_{4}\right)_{2} \mathrm{SO}_{4}, 0.5 \mathrm{~g} . \mathrm{MgSO}_{4} \cdot 7 \mathrm{H}_{2} \mathrm{O}, 2 \mathrm{mg}$. $\mathrm{FeCl}_{3} .6 \mathrm{H}_{2} \mathrm{O}, 2 \mathrm{mg}$. $\mathrm{MnSO}_{4}$, IO0O ml. tap water, $\mathrm{pH}$ adjusted to 6.8 with $\mathrm{KOH}$ ) supplemented with $\mathrm{I} \%$ (w/v) Nutrient Broth (Difco). Spirillum volutans was cultured in soft agar deeps of the same enriched medium except that the final concentration of agar was $2 \mathrm{~g}$./1.

Spirillum volutans grew poorly when subcultured from soft agar into liquid media. Additional stock cultures were maintained in unsupplemented Krieg's medium which was also

* Present address: Department of Biochemistry, University of Birmingham, Birmingham 15. 
used for growth experiments and for obtaining bacteria for respiration studies and enzyme analyses. Inocula of $\mathrm{I} \cdot 0 \mathrm{ml}$. were added to $\mathrm{I} 00 \mathrm{ml}$. of medium contained in a $250 \mathrm{ml}$. Erlenmeyer flask. After $48 \mathrm{~h}$. at $30^{\circ}$, these and similar $S$. serpens and $S$. itersonii cultures were used to seed $1 \cdot 21$. cultures contained in 21 . Fernbach flasks. These were incubated at $30^{\circ}$ for 2 days without agitation. All media to be inoculated with $S$. volutans were boiled to expel dissolved oxygen, and cooled immediately before use. Cultures were incubated in an air atmosphere. Growth was followed turbidimetrically with a Klett-Summerson colorimeter using a number 42 filter $(520 \mathrm{~nm}$.). Bacteria were harvested by centrifugation at I0,000 $\mathrm{g}$ for $10 \mathrm{~min}$., resuspended in $50 \mathrm{~mm}$-potassium phosphate buffer $(\mathrm{pH} 7 \cdot 4)$ resedimented by centrifugation and again suspended in phosphate buffer to give a final concentration of 20 to $40 \mathrm{mg}$. cell protein $/ \mathrm{ml}$.

Preparation of bacterial extracts. Bacteria were fractionated by the procedure of Gray, Wimpenny, Hughes \& Mossman (1966). Bacteria were ruptured by passing washed suspensions through an automated French pressure cell (Aminco, Silver Spring, Maryland, U.S.A.) cooled to $4^{\circ}$. Microscopic observations showed that breakage was complete after one passage. The treated suspension was centrifuged at $24,000 \mathrm{~g}$ for $20 \mathrm{~min}$. and the supernatant fluid recentrifuged at $144,000 \mathrm{~g}$ for $60 \mathrm{~min}$. The resultant high-speed supernatant is referred to as the HSS fraction. The residue from the initial centrifugation sedimented in two layers - an upper gelatinous layer above a paler, tightly packed pellet. The upper layer was removed with a spatula, resuspended in 50 mm-potassium phosphate buffer $\left(\mathrm{pH}_{7 \cdot 4}\right)$ and homogenized in a glass homogenizer (Kontes Glass Co., Vineland, New Jersey, U.S.A). The suspension was again centrifuged at $24,000 \mathrm{~g}$ and the upper layer of sediment removed and homogenized as before. The final suspension of cell-wall membrane (CWM) contained 5 to $15 \mathrm{mg}$. protein $/ \mathrm{ml}$. All manipulations were performed at $4^{\circ}$.

Respiration of bacterial suspensions. In most experiments oxygen consumption of bacterial suspensions was followed polarographically in an apparatus similar to that described by Lloyd \& Brookman (1967). Samples of the suspension (I to $10 \mathrm{mg}$. protein), substrates and inhibitors were mixed with air-saturated 50 mM-potassium phosphate buffer $\left(\mathrm{pH}_{7 \cdot 4}\right)$ to give a final volume of $2.0 \mathrm{ml}$. contained in the magnetically stirred reaction chamber. The sensitivity of respiration to cyanide and carbon monoxide was determined manometrically (Umbreit, Burris \& Stauffer, I964). Flasks were incubated at $30^{\circ}$ after flushing for $10 \mathrm{~min}$. with air or with an equal mixture of air and carbon monoxide.

Enzyme assays. Cytochrome oxidase and catalase were measured in bacterial suspensions. Cytochrome oxidase was assayed by measuring polarographically the rate of oxygen consumption in the presence of $1.5 \mathrm{~mm}$-ascorbate and $0.25 \mathrm{mM}-N N N^{\prime} N^{\prime}$-tetramethyl $p$-phenylenediamine (Slater, 1950). Assays were performed at room temperature, 22 to $24^{\circ}$. Catalase activity was determined polarographically by following $\mathrm{O}_{2}$ release from hydrogen peroxide by bacterial suspensions: activities were too low to measure spectrophotometrically. Washed bacterial suspension ( 0.2 to $5 \mathrm{mg}$. protein), $\mathrm{I} \cdot 8 \mathrm{ml}$. oxygen-free $50 \mathrm{~mm}$-potassium phosphate buffer $(\mathrm{pH} \mathrm{7.4)}$ ) and $0.1 \mathrm{ml}$. 250-fold diluted commercial hydrogen peroxide (reagent grade, $30 \%(\mathrm{w} / \mathrm{v})$ solution) were added to the reaction vessel, and the rate of increase of dissolved oxygen concentration (initially about $20 \%$ saturated) was determined. The observed rate was corrected by subtracting the rate of oxygen release from $\mathrm{H}_{2} \mathrm{O}_{2}$ in the absence of bacteria and by adding the endogenous rate of oxygen consumption by bacteria in the absence of $\mathrm{H}_{2} \mathrm{O}_{2}$. Since there are uncertainties in both corrections, the activities of catalase cited (Table 5) are approximations. Corrected activities were proportional to the volume of bacterial suspension assayed.

Aconitase, fumarase, malate dehydrogenase and isocitrate dehydrogenase activities of the 
high-speed supernatant and NADH oxidase and succinate dehydrogenase in the cell-wall membrane fractions were determined spectrophotometrically. Absorbancy changes at $30^{\circ}$ were recorded with a Unicam S.P. 500 spectrophotometer coupled to a Gilford 2000 multisample attachment (Gilford Instrument Labs. Inc., Ohio, U.S.A.).

Aconitase (citrate (isocitrate) hydro-lyase, EC 4.2.I.3) was measured by observing the increase in extinction at $233 \mathrm{~nm}$. in the presence of citrate (Anfinsen, 1955). Fumarase (L-malate hydrolase, EC 4.2.I.2) was assayed by observing the increase in extinction at $240 \mathrm{~nm}$. in the presence of malate (Massey, I955).

Malate dehydrogenase (L-malate: $\mathrm{NAD}^{+}$oxidoreductase, EC I. I I . 37) was determined by measuring the oxidation of NADH at $340 \mathrm{~nm}$. in the presence of oxaloacetate (Ochoa, $1955 a$ ) and isocitrate dehydrogenase (DL-isocitrate: NADP ${ }^{+}$oxidoreductase (decarboxylating), EC I.I.I.42) by following the reduction of $\mathrm{NADP}^{+}$at $340 \mathrm{~nm}$. in the presence of DL-isocitrate (Ochoa, 1955b).

NADH oxidase was measured by observing the decrease in NADH extinction at $340 \mathrm{~nm}$. (Slater, 1950) and succinic dehydrogenase (succinate: phenazine methosulphate oxidoreductase, EC I .5.99. I) by following the decrease in extinction at $600 \mathrm{~nm}$. of 2:6-dichlorophenolindophenol (Veeger, Der Vartanian \& Zeylemaker, 1969). The validity of each assay for each species was checked by establishing that reaction rates were independent of the substrate concentration(s), but were proportional to the volume of bacterial extract added.

Cytochromes. Cytochromes in both CWM and HSS fractions were identified and measured with a Cary I 5 recording spectrophotometer, and with a Cary I 4 spectrophotometer adapted for low-temperature spectroscopy. Difference spectra, dithionite reduced against ferricyanide oxidized, were obtained and cytochrome concentrations calculated by the method of Estabrook \& Holowinsky (196I) using the extinction coefficients for the analogous pigments in rat-liver mitochondria. For low-temperature spectroscopy (Estabrook, I96I) each cell extract, $0.8 \mathrm{ml}$., was mixed with $\mathrm{I} \cdot 2 \mathrm{ml} .50 \%(\mathrm{w} / \mathrm{v})$ sucrose in $50 \mathrm{~mm}$-potassium phosphate buffer ( $\mathrm{pH} 7 \cdot 4)$ and divided into two parts. These were oxidized and reduced at room temperature and injected with a syringe into perspex cuvettes immersed in liquid nitrogen.

The pyridine haemochromogens were determined by twice extracting bacterial suspensions with two volumes $0.4 \%$ (w/v) hydrochloric acid in acetone (Jacobs \& Wolin, 1963). The cell debris remaining after extraction was retained, and used to assay haem $c$. The acetone extracts were collected by centrifugation and decantation, combined, and evaporated to dryness in dimmed light at $40^{\circ}$ on a rotary evaporator. The residue was dissolved in petroleum ether (ligroine, b.p. 30 to $60^{\circ}$ ) and shaken with $50 \mathrm{ml}$. $0 . \mathrm{I}$ M-sodium bicarbonate. If an emulsion formed, this was broken by adding a few crystals of sodium chloride. The petroleum layer, which contained haem $b$, was collected and evaporated to dryness.

To the acetone extract or cell debris were added $0.5 \mathrm{ml} . \mathrm{N}-\mathrm{NaOH}, \mathrm{I} \cdot \mathrm{O} \mathrm{ml}$. reagent grade pyridine and $4.5 \mathrm{ml}$. water (Jacobs \& Wolin, I963). Reduced against oxidized difference spectra were recorded within I min. of adding alkali and pyridine. The reducing agent was taken from a fresh batch of reagent grade sodium dithionite, and the samples were shielded from light whenever possible. The cellular concentrations of protoporphyrin IX and haem $c$ were determined from the intensities of the $\alpha$ bands of their corresponding pyridine haemochromogens.

Cytochrome $o$ (Castor \& Chance, 1959) was determined by recording carbon monoxide difference spectra of unfractionated cell-free extracts supplemented with sodium succinate (Io mM-final concentration). An extract was flushed for $2 \mathrm{~min}$. with air-free carbon monoxide and its spectrum, relative to the untreated extract, was measured. The test sample was 
again flushed with carbon monoxide, and the cycle repeated until no further increase in extinction was observed at $419 \mathrm{~nm}$.

Benzoquinones were isolated from dense suspensions (40 to $100 \mathrm{mg}$. protein $/ \mathrm{ml}$.) by treating the bacteria with 4 volumes of methanol which had been cooled in acetone and dry ice, and then extracting lipids with 5 volumes of either chloroform or petroleum ether (ligroine, b.p. range 30 to $60^{\circ}$ ) (Redfearn, 1967 ). The solvent layer was collected by centrifugation before repeating the extraction. The combined extracts were evaporated to dryness at $40^{\circ}$ on a rotary evaporator, and the residue was dissolved in $5^{\circ} \mathrm{oml}$. ethanol. Difference spectra, silver oxide oxidized against sodium borohydride reduced, were recorded and the concentration of quinone determined from the peak height of $275 \mathrm{~nm}$. The spectra were identical to those of commercially available benzoquinone- 6 and benzoquinone- 10 . As the individual quinones were not identified, concentrations are expressed as absorbancy units $/ \mathrm{g}$. bacterial protein.

Protein was determined by the Folin method (Lowry, Rosebrough, Farr \& Randall, I95I). Bacterial numbers were determined microscopically by counting the number of organisms from a suitable dilution on a haemocytometer grid.

\section{RESULTS}

Growth characteristics. Spirillum volutans grew in air from small inocula only if the Krieg's medium was boiled for several minutes and rapidly cooled immediately before introducing the inoculum (Table I). Even with pretreatment, I \% (v/v) inocula were required to initiate growth when bacteria were taken from a 4-day or older culture, and no growth was observed when freshly inoculated cultures were shaken in air. Large inocula taken from young, motile cultures initially grew well even in media that had not been boiled, but growth often ceased after several generations. Spirillum itersonii and $S$. serpens gave dense cultures irrespective of the inoculum size or the pretreatment of the medium.

The final bacterial density in Krieg's medium differed markedly between species, but

Table I. The effect of aeration, and the treatment of the growth medium before inoculation, on the growth of Spirillum volutans

\begin{tabular}{|c|c|c|c|c|}
\hline \multirow[b]{2}{*}{$\begin{array}{l}\text { Pretreatment } \\
\text { of medium }\end{array}$} & \multirow[b]{2}{*}{$\begin{array}{l}\text { Inoculum size* } \\
\text { (organisms/ml.) }\end{array}$} & \multirow[b]{2}{*}{ Culturing conditions } & \multicolumn{2}{|c|}{$\begin{array}{c}\text { Cell density (organisms } / \mathrm{ml} \text {.) } \\
\text { after }\end{array}$} \\
\hline & & & $48 \mathrm{~h}$. & $96 \mathrm{~h}$. \\
\hline Boil; cool & $\begin{array}{l}5 \times 10^{5} \\
4 \times 10^{3} \\
4 \times 10^{3}\end{array}$ & $\begin{array}{l}\text { Stationary } \\
\text { Stationary } \\
\text { Shake }\end{array}$ & $\begin{array}{l}7 \times 10^{6} \\
8 \times 10^{4} \\
2 \times 10^{3}\end{array}$ & $\begin{array}{l}8 \times 10^{6} \\
9 \times 10^{5} \\
1 \times 10^{3}\end{array}$ \\
\hline Untreated & $\begin{array}{l}5 \times 10^{5} \\
4 \times 10^{3} \\
4 \times 10^{3}\end{array}$ & $\begin{array}{l}\text { Stationary } \\
\text { Stationary } \\
\text { Shake }\end{array}$ & $\begin{array}{l}5 \times 10^{8} \\
8 \times 10^{3} \\
2 \times 10^{3}\end{array}$ & $\begin{array}{l}5 \times 10^{6} \\
8 \times 10^{3} \dagger \\
1 \times 10^{3}\end{array}$ \\
\hline Boil; cool & $5 \times 10^{5}$ & $\begin{array}{l}\text { Stationary, pH frequently } \\
\text { readjusted to } 6 \cdot 8-7 \cdot 0\end{array}$ & $\mathrm{I} \times 10^{7}$ & - \\
\hline & $5 \times 10^{5}$ & $\begin{array}{l}\text { Stationary, } \mathrm{pH} \text { readjusted } \\
\text { and } 6 \mu \mathrm{mole} / \mathrm{ml} \text {. succinate } \\
\text { added after } 24 \mathrm{~h} \text {. }\end{array}$ & $2 \times 10^{7}$ & 一 \\
\hline
\end{tabular}

* The inoculum was taken from a culture $48 \mathrm{~h}$. old grown without shaking in unsupplemented Krieg's medium.

$\dagger$ These cultures gave variable results: growth usually stopped after one or two cell divisions, but occasionally more extensive growth was observed. 
varied little for duplicate cultures of the same species (Table 2). The $\mathrm{pH}$ of the medium increased during growth, which ceased when the $\mathrm{pH}$ rose to 8.4 , or somewhat lower in the case of Spirillum volutans. Attempts to increase the growth of $S$. volutans by buffering the medium were unsuccessful: 20 mM-tris (hydroxymethyl) aminomethane (tris) $(\mathrm{pH} \mathrm{7 \cdot 0)}$ 5 mM-potassium phosphate buffer (pH 6.8) completely inhibited its growth, although no similar effects were noted for $S$. serpens or $S$. itersonii. At concentrations above Io mM, sodium ions were also inhibitory for $S$. volutans. The final cell yield of $S$. volutans was greater when the $\mathrm{pH}$ was repeatedly adjusted to 6.8 with sterile sulphuric acid, and a further increase resulted on addition of more succinate (Table I).

Oxygen consumption of bacterial suspensions. Washed suspensions of Spirillum volutans consumed oxygen in the absence of added substrate but at a rate less than that of the other two spirilla (Table 3). Of the substrates tested, only succinate caused a marked stimulation of $S$. volutans respiration. The respiration of succinate and peptone by $S$. serpens and $S$. itersonii was 2 - to 35 -fold greater on an equivalent protein basis.

Table 2. Growth yields and final $p H$ in cultures of different spirilla in Krieg's medium

\begin{tabular}{lcc}
\multicolumn{3}{c}{$\begin{array}{c}\text { Increase in } \\
\text { Oensity after } 48 \mathrm{~h} .\end{array}$} \\
$\quad \begin{array}{ll}\text { (mg. dry wt } / \mathrm{l} \text { ) } \\
\text { Organism }\end{array}$ & Final $\mathrm{pH}$ \\
Spirillum volutans & 90 to $\mathrm{I} 40$ & $7 \cdot 4$ to $8 \cdot \mathrm{I}$ \\
S. itersonii & 450 to 480 & $8 \cdot \mathrm{I}$ to $8 \cdot 4$ \\
S. serpens & 250 to 290 & $8 \cdot \mathrm{I}$ to $8 \cdot 4$
\end{tabular}

Table 3. Rates of oxygen consumption by washed suspensions of three spirilla with various substrates

\begin{tabular}{lccc} 
Substrate & \multicolumn{3}{c}{$\begin{array}{c}\text { Oxygen consumption } \\
\text { (nmole/mg. protein/min.) }\end{array}$} \\
\cline { 2 - 4 } S. volutans & S. serpens & S. itersonii \\
None & $2 \cdot 2$ & 32 & 38 \\
mM-Succinate & 30 & 127 & 60 \\
5 mM-Glycerol & $2 \cdot 2$ & 42 & 52 \\
5 mM-Malate & $5 \cdot 8$ & 43 & 50 \\
I \% (v/v) Peptone & $3 \cdot 7$ & 128 & 58 \\
5 mM-Acetate & $3 \cdot 7$ & 65 & 32 \\
5 mM-Glutamate & $2 \cdot 2$ & 48 & 45
\end{tabular}

Table 4. Activities of some tricarboxylic acid cycle enzymes, NADH oxidase and catalase in three spirilla

\begin{tabular}{|c|c|c|c|c|}
\hline \multirow[b]{2}{*}{ Enzyme } & \multirow{2}{*}{$\begin{array}{c}\text { Cell } \\
\text { fraction }\end{array}$} & \multicolumn{3}{|c|}{$\begin{array}{c}\text { Enzyme activity } \\
(\mu \text { mole } / \mathrm{g} . \text { protein } / \mathrm{h} .)^{*}\end{array}$} \\
\hline & & S. volutans & S. serpens & S. itersonii \\
\hline Fumarase & HSS & $I \cdot 2$ & $25 \cdot I$ & $21 \cdot 8$ \\
\hline Malate dehydrogenase & HSS & $1 \cdot 5$ & 332 & I5I \\
\hline Aconitase & HSS & $3 \cdot 8$ & $3 I \cdot 2$ & $1 \cdot 9$ \\
\hline Isocitrate dehydrogenase & HSS & $5 \cdot 3$ & $16 \cdot 9$ & $18 \cdot 9$ \\
\hline Succinic dehydrogenase & CWM & $3 \cdot 8$ & $7 \cdot 2$ & $7 \cdot 1$ \\
\hline NADH oxidase & CWM & 0.7 & $9 \cdot 3$ & $24 \cdot 7$ \\
\hline Catalase & Whole cells & 2 & I6 & 75 \\
\hline
\end{tabular}

* Average of duplicate assays on 3 to 5 independent preparations. 


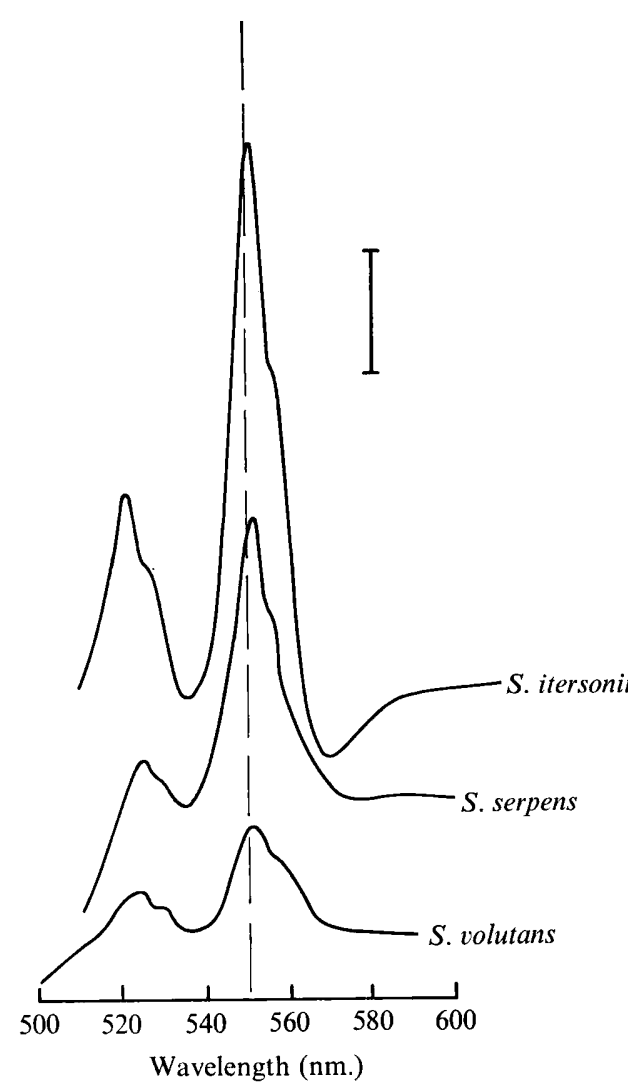

Fig. I

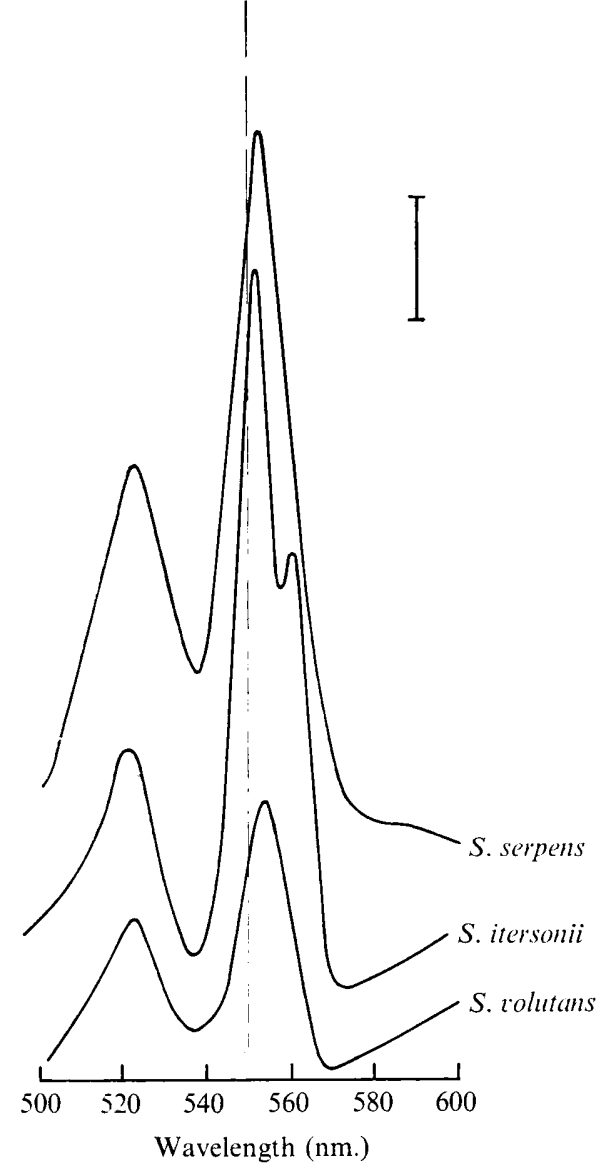

Fig. 2

Fig. I. Difference spectra of high-speed supernatant (HSS) extracts of Spirillum volutans, $S$. itersonii and $S$. serpens. The bacterial extract $(3.0 \mathrm{ml}$.) was transferred to two cuvettes. A few grains of sodium dithionite were added to the test sample, and one drop (approximately $0.05 \mathrm{ml}$.) of IO mM-potassium ferricyanide was added to the control cuvette. Spectra were recorded at room temperature with the Cary 15 spectrophotometer. The length of the vertical bar represents an absorbancy increment of 0.0I. The protein concentrations for the three HSS samples were $6.6 \mathrm{mg}$. $/ \mathrm{ml}$. (S. itersonii), $5.4 \mathrm{mg}$.) $\mathrm{ml}$. (S. serpens) and $4.2 \mathrm{mg} . / \mathrm{ml}$. (S. volutans).

Fig. 2. Difference spectra of cell-wall-membrane fractions of Spirillum volutans, $S$. itersonii and $S$. serpens. The experimental details were the same as for Fig. I. The protein concentrations were $13.0 \mathrm{mg} . / \mathrm{ml}$. (S. itersonii), $4.1 \mathrm{mg} . / \mathrm{ml}$. (S. serpens) and $10.0 \mathrm{mg} . / \mathrm{ml}$. (S. volutans).

Cyanide-inhibited Spirillum volutans respiration by $95 \%$, but carbon monoxide had little effect even after prolonged incubation of the organism in its presence. Tris, phosphate and sodium ions at concentrations that inhibit growth also caused a 30 to $40 \%$ decrease in the respiration of $S$. volutans. There was a significant decrease in respiration rate at $\mathrm{pH}$ values above the growth limiting level of about $8 \cdot 0$. Spirillum serpens and $S$. itersonii were sensitive to cyanide ( $95 \%$ at $5 \mathrm{~mm}-\mathrm{KCN})$ but not to any of the other compounds mentioned above.

Tricarboxylic acid cycle enzyme activities. HSS fractions of all three spirilla contained malate dehydrogenase, $\mathrm{NADP}^{+}$dependent isocitrate dehydrogenase, aconitase and fumarase 
activities, but succinic dehydrogenase was sedimented in the CWM fraction (Table 4). The activities of all tricarboxylic acid (TCA) cycle enzymes were lower on a protein basis in Spirillum volutans extracts, but only fumarase and malate dehydrogenase were especially deficient compared to the oxygen-insensitive spirilla. CWM fractions oxidized NADH, but once again this activity was low in $S$. volutans. Spirillum volutans can thus oxidize succinate to fumarate, but subsequent pyridine nucleotide dependent activities are weak.

Electron transfer-chain components. As succinate oxidation in the spirilla was cyanidesensitive, and membrane preparations oxidized NADH and succinate, the presence of a cytochrome-linked terminal electron transfer pathway to oxygen is probable. This was confirmed spectrophotometrically.

The cytochrome spectra of HSS and CWM extracts are shown in Fig. I and 2. All three spirilla synthesized appreciable quantities of cytochrome $b$ and $c$, but $a$-type cytochromes were not detected. This agrees with the insensitivity of oxygen consumption in the presence of succinate to carbon monoxide. Low-temperature spectra of whole-cell, soluble and membrane-bound cytochromes revealed that more than one $b$ - and $c$-type cytochrome was formed by the three spirilla. Although small variations in the positions of absorption maxima were noted, the spectra were similar in each species. The individual components are now being characterized, and will be the subject of a subsequent report. The concentrations of cytochromes in each cell fraction are compared in Table 5.

Spirillum volutans appeared to contain less cytochrome $c$ than the other two spirilla. This was confirmed by converting the cytochromes to their pyridine haemochromogen derivatives. Comparable quantities of the pyridine haemochromogen of protoporphyrin IX were obtained from all three organisms, but $S$. volutans contained less haem $c$ (Table 5).

Cytochrome oxidase. The endogenous rates of oxygen consumption of all three organisms doubled when I. 5 mM-ascorbate was added as the oxidizable substrate. This rate was further stimulated in the presence of $0.25 \mathrm{mM}-N N N^{\prime} N^{\prime}$-tetramethyl $p$-phenylenediamine, which is thought to pass electrons directly to cytochrome oxidase. Although the latter activity was lowest in Spirillum volutans $(72 \mathrm{nmole} / \mathrm{mg}$. protein $/ \mathrm{min}$. compared with $240 \mathrm{nmole} / \mathrm{mg} . / \mathrm{min}$. in S. serpens and $200 \mathrm{nmole} / \mathrm{mg}$. $/ \mathrm{min}$. in S. itersonii), it was still considerably greater than the peptone, succinate or malate supported respiration rates of this organism. It seems unlikely that cytochrome oxidase activity limits the rate at which oxygen can be reduced. This conclusion was supported by the observation that the respiration rate of a sonically

Table 5. Cytochrome o, haem and benzoquinone content of whole cells, and the concentration of cytochromes in cell-free extracts of spirilla

\begin{tabular}{|c|c|c|c|c|}
\hline Pigment assayed & Units & S. volutans & S. serpens & S. itersonii \\
\hline $\begin{array}{l}\text { Protohaeme (pyridine } \\
\text { haemochromogen) }\end{array}$ & pmole/g. dry wt & $2 \mathrm{I}$ & 22 & 26 \\
\hline $\begin{array}{l}\text { Haeme } c \text { (pyridine haemo- } \\
\text { chromogen) }\end{array}$ & pmole/g. dry wt & 25 & 72 & 78 \\
\hline Cytochrome $o$ & $\begin{array}{l}\text { Peak height at } \\
420 \mathrm{~nm} \text {./g. dry wt }\end{array}$ & 5 & 19 & I 2 \\
\hline Cytochrome $c$ in HSS & pmole/mg. protein & 107 & 193 & 343 \\
\hline Cytochrome $c$ in CWM & pmole/mg. protein & 99 & 708 & 220 \\
\hline Cytochrome $b$ in HSS* & pmole/mg. protein & 82 & I 58 & 236 \\
\hline Benzoquinone & $\begin{array}{l}\text { Extract volume } \\
\times \text { A } 275 \mathrm{~nm} . / \mathrm{g} \text {. dry } \\
\text { cell wt }\end{array}$ & $4 \cdot 4$ & $5 \cdot 4$ & $2 \cdot 7$ \\
\hline
\end{tabular}

* Cytochrome $b$ in the CWM fractions was masked by the high concentration of cytochrome $c$. No $a$-type cytochromes were detected. 
disrupted suspension of $S$. volutans was a little higher when both NADH and succinate were present than the sum of the rates with the individual substrates (Scholes \& Smith, 1968).

Quinones and catalase. Oxidation-reduction reactions have been described in which flavoproteins and quinones mediate the reduction of oxygen to hydrogen peroxide (Meister \& Wellner, 1963). These reactions by-pass the energy-conserving reactions of the cytochrome chain (but see Cox, Snoswell \& Gibson, 1968) and would be favoured in organisms which contain high concentrations of quinones. The resulting peroxide might be toxic if cells contained weak catalase activity. We therefore looked for quantitative differences in both the quinone concentrations and the catalase activity of the three spirilla. Similar quantities of benzoquinones were extractable from each organism (Table 5). No naphthoquinones were detected. In contrast, Spirillum volutans has a very low catalase activity (Table 4 ) which is, nevertheless, higher than its respiratory rate. Thus, accumulation of toxic peroxides (Stephenson, 1939; Dickens, 1946, 1962) is an unlikely mechanism for oxygen inhibition.

\section{DISCUSSION}

The data confirm the sensitivity of Spirillum volutans to oxygen first reported by Wells \& Krieg (1965). Compared to two oxygen insensitive spirilla, $S$. serpens and $S$. itersonii, $S$. volutans grows slowly and less abundantly and has a lower respiratory activity. Qualitatively, the three organisms have similar electron transfer-chain components and possess all enzymes of the Krebs cycle for which assays were performed. On a comparable weight or protein basis, total cytochromes and particularly cytochrome $c$ are significantly lower in $S$. volutans; its fumarase, malate dehydrogenase, and NADH oxidase activities are 10- to 200-fold less; and its catalase activity is very low. These findings suggest a possible explanation for its low growth rate and yield.

Succinate is the major energy source for Spirillum volutans growing in Krieg's medium. The enzyme data suggest that only the succinate dehydrogenase reaction could have major significance in funnelling electrons into its electron-transport chain. As a consequence, per unit of succinate metabolized, ATP yields and growth yields would be much lower in $S$. volutans than in the other two spirilla in which no enzymic impediment exist to the generation of NADH via the Krebs cycle and its subsequent oxidation. The slower growth and respiration rate of $S$. volutans may simply be a consequence of the low absolute level of succinate dehydrogenase. The low respiratory activity is not due to a cytochrome deficiency since the electron transfer to oxygen is not rate-limiting in the organism's respiration.

The low respiration rate of Spirillum volutans may account for its sensitivity to inhibition by oxygen, which is a widespread, if not universal, attribute of cells; the differences between different organisms being one of degree (Haugaard, 1968). It would appear a priori that the intracellular concentration (or the oxygen concentration at the cell boundary) would be the determinant. If oxygen entrance into a cell is an unregulated diffusion process, at a given external oxygen concentration $S$. volutans, which has a low respiration rate, should have a higher intracellular oxygen concentration than $S$. itersonii or $S$. serpens, which respire more rapidly. If some critical cellular process in all three organisms were equally sensitive to oxygen, inhibition of $S$. volutans would be expressed at a lower external partial pressure or concentration.

We are grateful to Drs J. B. Peter and M. Worsforld for facilities for recording lowtemperature spectra, and to Drs A. Brodie and P. Philips for advice about quinone extraction.

This investigation was supported in part by grant GB-6223 from the National Science Foundation. 


\section{REFERENCES}

ANFInSEN, C. B. (1955). Aconitase from pig heart muscle. Methods in Enzymology I, 695-696.

CAstor, L. N. \& ChANCE, B. (1959.) Photochemical determinations of the oxidase of bacteria. Journal of Biological Chemistry 234, I 587-I 592.

Cox, G. B., Snoswell, A. M. \& Gibson, F. (1968). The use of a ubiquinone-deficient mutant in the study of malate oxidation in Escherichia coli. Biochimica et biophysica acta $\mathbf{1 5 3}, \mathrm{I}-\mathbf{I} 2$.

Dickens, F. (1946). The toxic effects of oxygen on brain metabolism and on tissue enzymes. I. Brain metabolism. Biochemical Journal 40, I45-I7I.

Dickens, F. (1962). Neurochemistry, pp. 85I-869. Edited by K. A. C. Elliot, I. H. Page \& J. H. Quastel. Springfield, Illinois: Thomas.

EhrenBerg, C. G. (1838). Die Infusionthierchen als Vollkommene Organismen, pp. 73-86. Leipzig.

Estabrook, R. W. (196I). Haematin Enzymes, p. 436. Edited by J. E. Falk, R. Lamberg \& R. K. Morton. Oxford: Pergamon Press.

Estabrook, R. H. \& Holowinsky, A. (196I). Studies on the content and organization of the respiratory enzymes of mitochondria. Journal of Biophysical and Biochemical Cytology 9, 19-32.

Gray, C. T., WimpenNy, J. W. T., Hughes, D. E. \& Mossman, M. R. (I966). Regulation of metabolism in facultative bacteria. I. Structural and functional changes in Escherichia coli associated with shifts between the aerobic and anaerobic states. Biochimica et biophysica acta 117, 22-32.

HaugaARd, N. (1968). Cellular mechanisms of oxygen toxicity. Physiological Reviews 48, 31 I-373.

JACOBS, N. J. \& Wolin, M. J. (1963). Electron transport systems of Vibrio succinogenes. I. Enzymes and cytochromes of the electron transport system. Biochimica et biophysica acta 69, 18-28.

Lloyd, D. \& Brookman, J. S. G. (1967). An oxygen electrode reaction vessel. Biotechnology and Bioengineering 9, $27 \mathrm{I}-272$.

Lowry, O. H., Rosebrough, N. J., Farr, A. L. \& Randall, R. J. (195I). Protein measurement with the Folin phenol reagent. Journal of Biological Chemistry 193, 265-275.

McElroy, L. J., Wells, J. S. \& Krieg, N. R. (1967). Mode of extension of cell surface during growth of Spirillum volutans. Journal of Bacteriology 93, 499-50I.

MASSEY, V. (1955). Fumarase. Methods in Enzymology 1, 729-730.

Meister, A. \& WelLNER, D. (1963). Flavoprotein amino acid oxidases. In The Enzymes, vol. 7, pp. 609-648. Edited by P. D. Boyer, H. Lardy \& K. Myrbäck. New York and London: Academic Press.

Oснод, S. (1955a). Malate dehydrogenase from pig heart. Methods in Enzymology I, 735-736.

OCHOA, S. (1955 b). Isocitrate dehydrogenase (TPN ${ }^{+}$) from pig heart. Methods in Enzymology $\mathbf{1}, 699-700$.

REDFEARN, E. R. (1967). Isolation and determination of ubiquinone. Methods in Enzymology 10, 38I-384.

RitTenBerg, B. T. \& RitTenBerg, S. C. (1962). The growth of Spirillum volutans Ehrenberg in mixed and pure cultures. Archivfür Mikrobiologie 42, I38-153.

Scholes, P. B. \& SMITH, L. (1968). Composition and properties of the membrane-bound respiratory chain system of Micrococcus denitrificans. Biochimica et Biophysica acta 153, 365-375.

Slater, E. C. (1950). The components of the dihydrocoenzymase oxidase system. Biochemical Journal 46, 484-503.

StepHenson, M. (1939). Bacterial Metabolism, 2nd edn, pp. 55-58. London: Longmans.

Umbreit, W. W., BurRis, R. H. \& Stauffer, J. F. (1964). Manometric Techniques. Minneapolis: Burgess Publishing Co.

Veeger, C., Der Vartanian, D. V. \& Zeylemaker, W. P. (1969). Succinate dehydrogenase. Methods in Enzymology 13, 8I-90.

WeLLS, J. S. \& KRIEG, N. R. (1965). Cultivation of Spirillum volutans in a bacteria-free environment. Journal of Bacteriology 90, 817-8I8.

Williams, M. A. \& RitTenberg, S. C. (1957). A taxonomic study of genus Spirillum Ehrenberg. International Bulletin of Bacteriological Nomenclature and Taxonomy 7, 49-I I I. 